\title{
Menyintesis Literatur Dalam Penulisan Artikel
}

\author{
Titik Rahayu ${ }^{1}$, Syafrimen Syafril ${ }^{2}$, Ismail Suardi Wekke ${ }^{3}$ \\ ${ }^{1}$ Universiti Kebangsaan Malaysia, Email: p91583@ siswa.ukm.edu.my. \\ ${ }^{2}$ Universitas Negeri Islam (UIN) Raden Intan Lampung, Indonesia, Email: \\ syafrimen@radenintan.ac.id.
}

${ }^{2}$ Sekolah Tinggi Agama Islam Negeri (STAIN) Sorong, Indonesia; College University of Yayasan Pahang, Malaysia. Email: ismail@ stain-sorong.ac.id

\begin{abstract}
ABSTRAK
Artikel ini mengemukakan contoh dalam menunjukkan proses sintesis kepustakaan untuk dijadikan rujukan dalam penulisan artikel. Digunakan tiga langkah, diawali dengan menelusuri kepustakaan. Selanjutnya, menemukan ide utama setiap artikel. Terakhir menuliskan dengan gaya paraphrase, bukan dengan kutipan langsung. Dengan demikian, saat menuliskan artikel akan merujuk kepada ide-ide yang sudah dipublikasikan.
\end{abstract}

Kata Kunci: literatur; kepustakaan; penulisan.

\section{Pendahuluan}

Saat menulis artikel, ada dua tempat yang menjadi bagian yang wajib untuk merujuk terbitan atau publikasi sebelumnya yaitu pendahuluan dan pembahasan. Dengan mengemukakan referensi, akan menjadi pendukung dalam argumentasi sekaligus pembaca akan mendapatkan kesempatan dalam merujuk kembali literatur yang digunakan sebagai landasan dalam analisis yang dikemukakan. Artikel ini akan mengemukakan langkah demi langkah bagaimana proses dalam menyintesis informasi yang tersedia dalam pelbagai artikel kemudian dituliskan ulang untuk menjadi rujukan dalam penulisan artikel berikutnya. Artikel ini berawal dari versi asal yang dituliskan ulang dengan penambahan informasi dan juga penyuntingan (Rahayu, \& Syafril, 2018).

\section{Langkah-langkah Penulisan Sintesa Literatur}

Berikut ini langsung dalam bentuk contoh.

\section{Judul Penelitian:}

Keyakinan Diri Terhadap Kemahiran Pemikiran Komputasional Dalam Kalangan Calon Guru Sains

\section{A. Kemahiran Pemikiran Komputasional (Computer Thingking)}

\begin{tabular}{|l|l|}
\hline Wing (2006) & $\begin{array}{l}\text { Pemikiran pengiraa melibatkan "menyelesaikan } \\
\text { masalah berbentuk sistem, dan memahami tingkah laku } \\
\text { manusia, dengan menggambarkan pada konsep-konsep } \\
\text { asas sains komputer". }\end{array}$ \\
\hline
\end{tabular}




\begin{tabular}{|c|c|}
\hline $\begin{array}{l}\text { Astrachan, Hambrusch, } \\
\text { Peckham, \& Settle (2009) }\end{array}$ & $\begin{array}{l}\text { Pemikiran komputasi dianggap sebagai set alat } \\
\text { penyelesaian masalah yang melampaui teknologi } \\
\text { maklumat (IT), kelancaran untuk memohon prinsip } \\
\text { pengkomputeran seperti abstraksi, penguraian, } \\
\text { generalisasi, pengiktirafan corak, dan pemikiran } \\
\text { algoritma dan selari. }\end{array}$ \\
\hline Cuny et al. (2010) & $\begin{array}{l}\text { Proses pemikiran yang terlibat dalam merumuskan } \\
\text { masalah dan penyelesaian supaya penyelesaian diwakili } \\
\text { dalam bentuk yang boleh menjadi keberkesanan-tively } \\
\text { dijalankan oleh ejen memproses maklumat. }\end{array}$ \\
\hline $\begin{array}{l}\text { Computer Science Teachers } \\
\text { Association (CSTA) and the } \\
\text { International Society for } \\
\text { Technology in Education } \\
\text { (ISTE) (2011) }\end{array}$ & $\begin{array}{l}\text { Pendekatan untuk menyelesaikan masalah dengan cara } \\
\text { yang boleh dilaksanakan dengan komputer. } \\
\text { Menggunakan satu set konsep, seperti abstraksi, rekursi, } \\
\text { dan lelaran, untuk memproses dan menganalisis data, } \\
\text { serta untuk membuat artifak sebenar dan maya. }\end{array}$ \\
\hline Barr \& Stephenson (2011) & $\begin{array}{l}\text { Metodologi penyelesaian masalah yang boleh automatik } \\
\text { dan dipindahkan serta digunakan merentasi subjek. }\end{array}$ \\
\hline Swaid (2015) & $\begin{array}{l}\text { Melibatkan penyelesaian masalah, bentuk sistem, dan } \\
\text { memahami tingkah laku manusia, dengan melukis pada } \\
\text { konsep-konsep asas kepada Sains Komputer dan juga } \\
\text { Pemikiran Komputasional termasuk pelbagai alat } \\
\text { pemikiran yang mencerminkan keluasan bidang Sains } \\
\text { Komputer. }\end{array}$ \\
\hline Aho (2012) & $\begin{array}{l}\text { Pemikiran komputasional sebagai proses pemikiran yang } \\
\text { melibatkan perumusan masalah sehingga pelajar boleh } \\
\text { menyelesaikan masalah melalui langkah-langkah } \\
\text { pengiraan dan algoritma. }\end{array}$ \\
\hline Selby \& Woollard (2013) & $\begin{array}{l}\text { Proses kognitif atau mental, manusia, bukan mesin, } \\
\text { penyelesaian masalah dalam erti kata yang luas, dan } \\
\text { melibatkan kebolehan seperti: Abstraksi (penakulaan), } \\
\text { iaitu menyembunyikan kerumitan realiti yang wujud; } \\
\text { penguraian, membahagikan tugas atau masalah kedalam } \\
\text { bahagian mudah supaya lebih mudah menyelesaikan } \\
\text { masalah yang rumit; Algoritma, menentukan tugas } \\
\text { sebagai satu set langkah demi langkah dengan memiliki } \\
\text { arahan yang mudah; Penilaian, menilai kelebihan dan } \\
\text { batasan penyelesaian; serta Pengumuman, iaitu keadaan } \\
\text { khusus ke lebih umum. }\end{array}$ \\
\hline Selby $(\underline{2015})$ & $\begin{array}{l}\text { Pemikiran komputasi boleh dianggap sebagai set alat } \\
\text { penyelesaian masalah yang melampaui teknologi } \\
\text { maklumat (IT) kelancaran untuk memohon prinsip } \\
\text { pengkomputeran seperti abstraksi, penguraian, } \\
\text { generalisasi, pengiktirafan corak, dan pemikiran } \\
\text { algoritma dan selari. }\end{array}$ \\
\hline
\end{tabular}




\begin{tabular}{|c|c|}
\hline Csizmadia, A. et al. (2015) & $\begin{array}{l}\text { Pemikiran Komputasional } \\
\text { penyelesaian masalah yang memerlukan usaha } \\
\text { memecahkan sesuatu masalah kepada komponen yang } \\
\text { lebih kecil (Decompose), cuba mengekstrak idea ataupun } \\
\text { maklumat yang penting dan relevan (Abstraction), } \\
\text { mengenali corak (Pattern) yang membolehkan } \\
\text { perancangan penyelesaian yang tepat bagi mengelakkan } \\
\text { ulangan dan tindakan yang kurang releven supaya } \\
\text { meningkatkan keberkesanan proses penyelesaian } \\
\text { masalah tersebut. Individu perlu menggunakan } \\
\text { pemikiran logikal (Logical Reasoning) bagi } \\
\text { mengenalpasti maklumat yang penting dan mengaturkan } \\
\text { langkah penyelesaian mengikut turutan yang logikal } \\
\text { (Algorithm), menilai pemilihan dan keputusan yang } \\
\text { telah dilakukan bagi menguji kesahihan dan keboleh } \\
\text { laksanaan prosedur tersebut (Evaluation). }\end{array}$ \\
\hline $\begin{array}{l}\text { Meng-Chuan Tsai, \& Chia- } \\
\text { Wen Tsai (2017) }\end{array}$ & $\begin{array}{l}\text { Co mputational thinking involves solving problems, } \\
\text { designing systems, and understanding human behavior, } \\
\text { by drawing on the concepts fundamental to computer } \\
\text { science } \\
\text { Pemikiran komputasi melibatkan menyelesaikan } \\
\text { masalah, merancang sistem, dan memahami tingkah laku } \\
\text { manusia, dengan menarik konsep-konsep asas kepada } \\
\text { sains komputer }\end{array}$ \\
\hline
\end{tabular}

\section{Teknik Sintesis Berbagai Pandangan di Atas:}

Untuk melakukan sintesis secara manual terhadap berbagai pandangan tentang pemikiran komputasional seperti dipaparkan di atas, kita perlu membaca, memahami dan menganalisis informasi yang disampaikan oleh penulis dalam konsep yang mereka kemukakan. Untuk memudahkan melakukan itu, bisa dilakukan dengan mengambil poin-poin atau kata kuncikata kunci yang digunakan oleh penulis dalam mengemukakan konsep mereka. Seterusnya setiap konsep yang sama atau memiliki makna yang lebih kurang sama, boleh kita sintesiskan menjadi satu ide, sehingga dalam melaporkan kita menghindari maklumat yang berulang. Dalam melakukan penelitian ilmiah, sebenarnya yang kita kutip itu adalah "ide" bukan mengulang penulisan semua yang ditulis oleh penulis sebelum kita. Begitulah seterusnya proses yang perlu kita lakukan dalam mengambil berbagai ide orang lain untuk dimasukan ke dalam penulisan kita. Pekerjaan mensintesiskan berbagai pandangan orang lain ini akan lebih mudah dilakukan dengan menggunakan software NVIVO.

\section{Contoh Hasil Sintesis dari Berbagai Pandangan Pakar:}

Secara keseluruhan para pakar bersetuju bahawa kemahiran pemikiran komputasional adalah satu kemahiran sebagai alat penyelesaian masalah dalam kehidupan manusia (Aho 2012; Astrachan, Hambrusch, Peckham, \& Settle 2009; Barr \& Stephenson 2011; Computer Science Teachers Association (CSTA) and the International Society for Technology in 
Education (ISTE) 2011; Csizmadia, A. et al. 2015; Cuny et al. 2010; Meng-Chuan Tsai, ChiaWen Tsai 2017; Selby dan Woollard 2013; Selby 2015; Swaid 2015; Wing 2006). Meskipun demikian, terdapat beberapa perbezaan pendapat daripada aspek-aspek yang berkaitan dengan definisi kemahiran pemikiran komputasional yang dipaparkan pakar-pakar tersebut. MengChuan Tsai, Chia-Wen Tsai (2017) dan Wing (2006) memiliki definisi yang sama terhadap kemahiran pemikiran komputasional, iaitu pemikiran komputasional yang melibatkan menyelesaikan masalah, merancang sistem, dan memahami tingkah laku manusia, dengan menarik konsep-konsep asas kepada sains komputer. Berdasarkan definisi pandangan MengChuan Tsai, Chia-Wen Tsai (2017) dan Wing (2006) tersebut kemahiran pemikiran komputasional tidak hanya melibatkan teknologi perkomputeran dalam menyelesaikan masalah, namun dapat dilakukan melalui tanpa bantuan teknologi perkomputeran seperti tingkah laku manuasia. Contohnya, dalam menggunakan teknik leraian boleh digunakan untuk menyelesaikan masalah dengan memisahkan beberapa jenis bahan kepada beberapa bahagian yang lebih kecil dan ringkas (anonim 2018). Dalam perspektif lain, Astrachan, Hambrusch, Peckham, dan Settle (2009) dan Selby (2015) mendefinisikan kemahiran pemikiran komputasional yang berfokus terhadap set alat penyelesaian masalah yang melampaui teknologi maklumat (IT) melalui prinsip perkomputeran seperti abstraksi, penguraian, generalisasi, pengiktirafan corak, dan pemikiran algoritma dan parallelism.

\section{A.1 Kepentingan ICT Untuk Masa Depan}

\begin{tabular}{|l|l|}
\hline Gareis et al. (2014) & $\begin{array}{l}\text { Kemahiran yang sama kekurangan dan impak ekonomi } \\
\text { seterusnya telah diramalkan oleh orang Eropah. Suruhanjaya, } \\
\text { mendorong panggilan untuk integrasi kemahiran digital ke } \\
\text { peringkat awal peringkat pendidikan sekolah. }\end{array}$ \\
\hline $\begin{array}{l}\text { The Chartered Institute for } \\
\text { IT (2010) }\end{array}$ & $\begin{array}{l}\text { Membekalkan kanak-kanak dengan kemahiran pemikiran } \\
\text { komputasi asas yang akan menyokong penyertaan dalam } \\
\text { kami masyarakat digital dan ekonomi adalah penting untuk } \\
\text { kemakmuran masa depan. }\end{array}$ \\
\hline $\begin{array}{l}\text { Yadav, Mayfield, Zhou, } \\
\text { (2014) }\end{array}$ & $\begin{array}{l}\text { pemikiran komputasional mempunyai potensi untuk } \\
\text { memajukan kemahiran dan kebolehan penyelesaian masalah } \\
\text { pelajar dengan ketara kerana mereka mula berfikir dengan } \\
\text { cara yang baru. }\end{array}$ \\
\hline Selby (2015) & $\begin{array}{l}\text { Baru-baru ini, pemikiran komputasi (CT) telah dianjurkan } \\
\text { sebagai abad kedua puluh satu kemahiran yang perlu dimiliki } \\
\text { pelajar untuk membangunkan kemahiran menyelesaikan } \\
\text { masalah menggunakan prinsip dari sains komputer. }\end{array}$ \\
\hline Lye, \& Koh (2014) & $\begin{array}{l}\text { Untuk pemikiran komputasi untuk menjadi sebahagian } \\
\text { daripada kurikulum K-12, ada keperluan kritikal untuk } \\
\text { menyediakan guru yang baik dilatih untuk mengintegrasikan } \\
\text { pemikiran komputasi dalam aktiviti pedagogi harian mereka } \\
\text { (Lye \& Koh, 2014). }\end{array}$ \\
\hline
\end{tabular}




\section{A.2 Membangun Kemahiran Pemikiran Komputasi}

\begin{tabular}{|l|l|}
\hline Blank et al. (2003) & $\begin{array}{l}\text { Sastera pendidikan Sains Komputasi mencadangkan banyak } \\
\text { cara untuk berkembang keupayaan berfikir komputasi } \\
\text { pelajar. Sastera mengesyorkan menghubungkan. Pemikiran } \\
\text { komputasi kepada kepentingan pelajar (Resnick et al., 2009), } \\
\text { melalui komputer permainan (Carter, 2006, Lenox, Jesse, \& } \\
\text { Woratschek, 2012) atau berasaskan multimedia tugas } \\
\text { pembelajaran (Blank et al., 2003). }\end{array}$ \\
\hline $\begin{array}{l}\text { Repenning, Webb, \& } \\
\text { Ioannidou (2010) }\end{array}$ & $\begin{array}{l}\text { Pendekatan berasaskan Permainan telah ditunjukkan kepada } \\
\text { meningkatkan keseronokan pembelajaran komputasi pelajar } \\
\text { semasa membangunkan Komputasi Konsep pemikiran. }\end{array}$ \\
\hline $\begin{array}{l}\text { Stephenson, Gal-Ezer, } \\
\text { Verno (2005) }\end{array}$ & $\begin{array}{l}\text { Pengalaman pembelajaran yang bermakna dapat dicapai } \\
\text { dengan merancang bahan kursus itu menggabungkan; } \\
\text { pendekatan penyelesaian masalah, persekitaran eksperimen } \\
\text { dengan penekanan pada pengalaman dunia sebenar yang } \\
\text { sahih. }\end{array}$ \\
\hline $\begin{array}{l}\text { Repenning \& Ioannidou } \\
(2008)\end{array}$ & $\begin{array}{l}\text { Kepuasan pelajar dengan pengkomputeran boleh ditingkatkan } \\
\text { dengan menyokong kemahiran di luar pengaturcaran dan ini } \\
\text { mungkin bahkan meluaskan penyertaan selanjutnya. }\end{array}$ \\
\hline $\begin{array}{l}\text { Barr \& Stephenson } \\
\text { (2011) }\end{array}$ & $\begin{array}{l}\text { Berhujah bahawa pelajar hari ini akan tinggal dan bekerja di } \\
\text { dunia yang banyak dipengaruhi dengan mengira prinsip. Jika } \\
\text { matlamat kita adalah untuk memupuk generasi dengan } \\
\text { kemahiran CT, kita perlu membiasakan pelajar dengan CT } \\
\text { dalam pendidikan K-12 awal [Barr dan Stephenson 2011]. }\end{array}$ \\
\hline
\end{tabular}

\section{B. Kajian Relavan Self Confidence}

\begin{tabular}{|l|l|}
\hline Bower et. Al. & $\begin{array}{l}\text { Kepercayaan para guru tentang keupayaan pelajar } \\
\text { untuk meningkatkan kemampuan Pemikiran Komputasi } \\
\text { mereka. Seramai } 140 \text { orang guru menanggapi penarafan } \\
\text { soalan dengan tahap keyakinan mereka membangunkan } \\
\text { keupayaan berfikir komputasi pelajar (Sangat tidak yakin 8, } \\
\text { tidak yakin 24, sedikit tidak yakin 18, sedikit yakin 42, yakin } \\
\text { 45, sangat yakin 3. } \\
\text { Sebanyak } 122 \text { guru menjawab soalan "Apa yang menghalang } \\
\text { anda daripada merasa yakin tentang membangunkan } \\
\text { keupayaan berfikir pengkomputeran anda? "Of ini, 31 } \\
\text { responden menyatakan bahawa kekurangan pengetahuan } \\
\text { tentang topik itu menghalang mereka daripada merasa yakin } \\
\text { dalam mengajar pemikiran komputasi, ini jawapan umumnya } \\
\text { mencerminkan kekurangan pemahaman pemikiran komputasi } \\
\text { konsep, misalnya "mempunyai pemahaman yang kuat } \\
\text { tentang konsep yang terlibat, mengetahui jika saya bergerak } \\
\text { ke arah yang betul. "Terdapat 21 guru sahaja menjawab }\end{array}$ \\
\hline
\end{tabular}




\begin{tabular}{|c|c|}
\hline & $\begin{array}{l}\text { bahawa mereka kurang yakin kerana mereka tidak menyedari } \\
\text { apa Pemikiran komputasi adalah, sebagai contohnya "Jika } \\
\text { saya tahu apa yang sebenarnya saya tidak akan mempunyai } \\
\text { masalah mengajarnya " }\end{array}$ \\
\hline $\begin{array}{l}\text { Bower \& Katrina Falkner } \\
\text { (2015) }\end{array}$ & $\begin{array}{l}\text { Terdapat } 32 \text { orang guru pra-perkhidmatan yang memilih } \\
\text { untuk bertindak balas kepada soalan-soalan yang berkaitan } \\
\text { dengan bagaimana yakin mereka merasakan untuk } \\
\text { membangunkan keupayaan pemikiran pengiraan pelajar } \\
\text { mereka (lihat Rajah 1). Daripada graf ia boleh dilihat bahawa } \\
18 \text { daripada } 32 \text { orang guru pra-perkhidmatan (56\%) } \\
\text { menyatakan bahawa mereka ke tahap yang tidak yakin dan } \\
\text { bukan yakin mengajar pemikiran pengiraan. }\end{array}$ \\
\hline & $\begin{array}{l}\text { Apabila guru praperkhidmatan ditanya "apa yang } \\
\text { menghalang anda daripada merasa yakin tentang } \\
\text { membangunkan keupayaan pemikiran pengiraan pelajar } \\
\text { anda?" Jawapan yang berkaitan dengan isu-isu pedagogi, isu- } \\
\text { isu teknologi, isu-isu umum, keadaan dan isu-isu afektif. } \\
\text { Sembilan guru praperkhidmatan berasa tidak yakin tentang } \\
\text { pembangunan mereka pengiraan pelajar berfikir kerana isu- } \\
\text { isu pedagogi, termasuk ketidakbiasaan dengan kurikulum (5), } \\
\text { kekurangan strategi pedagogi (3), kekurangan idea } \\
\text { pengajaran (1), dan ketidakpastian bagaimana untuk } \\
\text { memohon pemikiran pengiraan kepada situasi dunia sebenar } \\
\text { (1). Terdapat lapan orang guru pra-perkhidmatan yang } \\
\text { merasakan bahawa mereka tidak mempunyai pengetahuan } \\
\text { teknologi dan pengalaman untuk merasa yakin tentang } \\
\text { mengajar pemikiran pengiraan, walaupun ramai ini muncul } \\
\text { untuk menjadi pemikiran pengiraan mengelirukan dengan } \\
\text { penggunaan teknologi am (misalnya "Saya tidak mempunyai } \\
\text { pengetahuan ICT" ). Salah satu daripada guru-guru } \\
\text { praperkhidmatan berasa ia tidak mempunyai bidang sains } \\
\text { komputer dan pengaturcaraan pengetahuan yang diperlukan. } \\
\text { Terdapat tiga belas guru pra-perkhidmatan yang menyatakan } \\
\text { lebih banyak sebab umum untuk kekurangan mereka } \\
\text { keyakinan termasuk pemahaman yang lemah sebanyak apa } \\
\text { pengiraan cara pemikiran (4), kekurangan umum } \\
\text { pengetahuan (6) dan kekurangan umum pengalaman (3). Dua } \\
\text { orang guru pra-perkhidmatan tidak berasa yakin mengajar } \\
\text { pemikiran pengiraan kerana mengikut keadaan faktor-faktor } \\
\text { yang berkaitan dengan menjadi seorang guru: Masih belajar } \\
\text { tentang menjadi seorang guru supaya tidak lagi yakin dalam } \\
\text { mana-mana kawasan tertentu Saya tidak tidak diajar seperti } \\
\text { ini di sekolah, kandungan dan penggunaan Teknologi } \\
\text { Seorang guru pra-perkhidmatan bercakap langsung tentang } \\
\text { takut yang tidak dikenali yang memberi kesan kepada } \\
\text { keyakinan mereka yang: Kerana ia adalah sesuatu yang baru } \\
\text { kepada saya dan untuk mengajar sesuatu yang i am hanya } \\
\text { datang kepada terma dengan sedikit menakutkan saya dan } \\
\text { saya hilang keyakinan kerana itu. }\end{array}$ \\
\hline
\end{tabular}




\begin{tabular}{|c|c|}
\hline $\begin{array}{l}\text { Allan et al. (2010); Garcia } \\
\text { et al. (2010); Henderson et } \\
\text { al. (2007); Wing (2008) }\end{array}$ & $\begin{array}{l}\text { penyelidik lain juga telah kurang menjaringkan kepentingan } \\
\text { pemikiran pengiraan seluruh disiplin di peringkat K-16 }\end{array}$ \\
\hline $\begin{array}{l}\text { Yadav, Mayfield, Zhou, } \\
\text { Hambrusch, S., \& Korb } \\
(2014)\end{array}$ & $\begin{array}{l}\text { Pemikiran pengiraan (CT) ditakrifkan secara umum sebagai } \\
\text { aktiviti mental untuk pengabstrakan masalah dan } \\
\text { penyelesaian formu-Lating yang boleh diautomasikan. } \\
\text { Dalam masyarakat yang berasaskan maklumat semakin, CT } \\
\text { menjadi satu kemahiran yang penting untuk semua orang. } \\
\text { Untuk memastikan bahawa pelajar membangunkan } \\
\text { keupayaan ini di peringkat K-12, adalah penting untuk } \\
\text { menyediakan guru dengan pengetahuan yang mencukupi } \\
\text { tentang CT dan bagaimana untuk menggabungkan ia ke } \\
\text { dalam pengajaran mereka. Artikel ini menerangkan kajian } \\
\text { mengenai bentuk dan memperkenalkan modul pemikiran } \\
\text { pengiraan dan menilai kesannya terhadap kefahaman guru } \\
\text { preservice 'konsep CT, serta sikap mereka terhadap com- } \\
\text { Puting. Keputusan menunjukkan bahawa memperkenalkan } \\
\text { pemikiran pengiraan ke dalam kursus pendidikan berkesan } \\
\text { boleh mempengaruhi pemahaman guru preservice 'konsep } \\
\text { CT. }\end{array}$ \\
\hline $\begin{array}{l}\text { Yadav, Mayfield, Zhou, } \\
\text { Hambrusch, \& Korb } \\
(2014)\end{array}$ & $\begin{array}{l}\text { Keputusan juga menggambarkan bahawa tidak ada } \\
\text { keseimbangan antara jantina, iaitu lakilaki lebih tinggi } \\
\text { minatnya terhadap pemikiran komputasional dibanding } \\
\text { perempuan. Namun, dalam hal ini jantina bukan merupakan } \\
\text { faktor penentu kemahiran pemikiran komputasional.Dalam } \\
\text { kajian bahawa, tidak ada interaksi yang signifikan antara } \\
\text { keadaan dan jantina. Perempuan pada masa ini kurang diberi } \\
\text { perhatian dalam keseluruhan saluran pendidikan } \\
\text { pengkomputeran. }\end{array}$ \\
\hline [Board 2012] & $\begin{array}{l}\text { Data terkini dari Lembaga Kolej menunjukkan bahawa hanya } \\
22 \% \text { daripada AP Penuntut ujian Sains Komputer adalah } \\
\text { wanita. }\end{array}$ \\
\hline $\begin{array}{l}\text { Yadav, Mayfield, Zhou, } \\
\text { Hambrusch, \& Korb } \\
\text { (2014) }\end{array}$ & $\begin{array}{l}\text { Penemuan dalam kajian kami menggalakkan, kerana mereka } \\
\text { mencadangkan bahawa wanita dan lelaki sama-sama selesa } \\
\text { dengan pengkomputeran, dan kedua-duanya melihat } \\
\text { pengkomputeran memainkan peranan dalam karier mereka. } \\
\text { Membina keselesaan ini dan pemahaman bahawa } \\
\text { pengkomputeran memainkan peranan penting dalam pelbagai } \\
\text { kerjaya boleh memainkan peranan penting dalam } \\
\text { meningkatkan bilangan wanita yang mengejar sains } \\
\text { komputer. }\end{array}$ \\
\hline
\end{tabular}




\section{Memperkenalkan Computer Thingking Dengan Bahasa Sederhana Berkaitan Dengan Keseharian}

\begin{tabular}{|l|l|}
\hline Yadav, Mayfield, Zhou, & Kelas pertama diperkenalkan pelajar definisi pemikiran \\
pengiraan dan lima konsep CT: Pengenalpastian Masalah \\
dan penguraian, pengambilan, pemikiran logik, algoritma, \\
dan debugging. Memandangkan guru preservice tidak \\
mempunyai sebelum latar belakang sains komputer, kita \\
digambarkan konsep-konsep ini dengan contoh-contoh \\
konkrit dari kehidupan sehari-hari dan yang berkaitan \\
istilah dengan pengalaman peribadi guru preservice '. kelas \\
bermula dengan pengajar meminta sepasang pelajar untuk \\
membangunkan arah pemanduan dari titik A ke titik B. \\
pengajar ini telah membawa pelajar dalam perbincangan \\
bagaimana mereka datang dengan arahan (mengenal \\
mereka, dilakarkan peta, mengambil yang terbaik laluan, \\
bertanya kepada seorang rakan, dan lain-lain) dan \\
bagaimana menyeluruh arahan mereka adalah (beberapa \\
langkah, terperinci turn-oleh-belok) menggunakan soalan \\
clicker.
\end{tabular}

\section{Komponen Computational Thingking}

\begin{tabular}{|l|l|}
\hline Wing (2006) & $\begin{array}{l}\text { menyatakan bahawa kemahiran pemikiran komputasional } \\
\text { asas adalah Leraian (Decomposition), Pengecaman corak } \\
\text { (Pattern Recognition), Penskalaan } \\
\text { (Abstraction), dan Pengitlakan (Algorithms). }\end{array}$ \\
\hline Barr \& Stephenson (2011) & $\begin{array}{l}\text { proposed nine core computational thinking concepts and } \\
\text { abilities to integrate CT concepts in K-12 classrooms } \\
\text { across core content areas. These core computational } \\
\text { thinking ideas include data collection, data analysis, data } \\
\text { representation, problem decomposition, abstraction, } \\
\text { algorithms and procedures, automation, parallelization, } \\
\text { and simulation. }\end{array}$ \\
\hline $\begin{array}{l}\text { Jurnal: } \\
\text { in Teacher Education }\end{array}$ & $\begin{array}{l}\text { These computational thinking concepts can be } \\
\text { implemented in K-12 classrooms through digital } \\
\text { storytelling, data collection and analysis, and scientific } \\
\text { investigations (Lee, Martin \& Apone, 2014), creating } \\
\text { games (Howland \& Good, 2015; Lee et al., 2014; }\end{array}$ \\
\hline
\end{tabular}




\begin{tabular}{|c|c|}
\hline & $\begin{array}{l}\text { Nickerson, Brand, \& Repenning, 2015), educational } \\
\text { robotics (Atmatzidou \& Demetriadis, 2014), physics } \\
\text { (Dwyer, Boe, Hill, Franklin, \& Harlow, 2013), visual } \\
\text { programming languages like Scratch or other interactive } \\
\text { media (Brennan \& Resnick, 2012; Calao, Moreno-Leon, } \\
\text { Correa, \& Robles, 2015), and even through maker } \\
\text { movements (Rode et al., 2015). }\end{array}$ \\
\hline $\begin{array}{l}\text { Computer Science Teachers } \\
\text { Association (CSTA) and the } \\
\text { International Society for } \\
\text { Technology } \\
\text { in Education (ISTE) }\end{array}$ & $\begin{array}{l}\text { Mereka menggunakan satu set konsep, seperti bstraksi, } \\
\text { rekursi, dan lelaran, untuk memproses dan menganalisis } \\
\text { data, dan untuk membuat artifak sebenar dan maya. }\end{array}$ \\
\hline Aho (2012) & $\begin{array}{l}\text { Pemikiran komputasional sebagai proses pemikiran yang } \\
\text { melibatkan perumusan masalah sehingga pelajar boleh } \\
\text { menyelesaikan masalah melalui langkah-langkahpengiraan } \\
\text { dan algoritma. Manakala Selby dan Woollard (2013) } \\
\text { mengartikan pemikiran komputasional sebagai proses } \\
\text { kognitif atau mental, manusia, bukan mesin, penyelesaian } \\
\text { masalah dalam erti kata yang luas, dan melibatkan } \\
\text { kebolehan seperti: Abstraksi (Penskalaan), iaitu } \\
\text { menyembunyikan kerumitan realiti yang wujud untuk } \\
\text { mewakili aspek pentingnya sahaja; Penguraian, } \\
\text { membahagikan tugas atau masalah ke dalam bahagian } \\
\text { mudah supaya lebih mudah menyelesaikan masalah yang } \\
\text { rumit; Algoritma, menentukan tugas sebagai satu set } \\
\text { langkah demi langkah dengan memiliki arahan yang } \\
\text { mudah; Penilaian, menilai kelebihan dan batasan } \\
\text { penyelesaian; serta Pengumuman, iaitu keadaan khusus ke } \\
\text { lebih umum. }\end{array}$ \\
\hline Csizmadia, et al. (2015) & $\begin{array}{l}\text { Pemikiran Komputasional merupakan proses penyelesaian } \\
\text { masalah yang memerlukan usaha memecahkan sesuatu } \\
\text { masalah kepada komponen yang lebih kecil (Decompose), } \\
\text { cuba mengekstrak idea ataupun maklumat yang penting } \\
\text { dan relevan (Abstraction), mengenali corak (Pattern) yang } \\
\text { membolehkan perancangan penyelesaian yang tepat bagi } \\
\text { mengelakkan ulangan dan tindakan yang kurang releven } \\
\text { supaya meningkatkan keberkesanan proses penyelesaian } \\
\text { masalah tersebut. Individu perlu menggunakan pemikiran } \\
\text { logikal (Logical Reasoning) bagi mengenalpasti maklumat } \\
\text { yang penting dan mengaturkan langkah penyelesaian } \\
\text { mengikut turutan } \\
\text { yang logikal (Algorithm), menilai pemilihan dan } \\
\text { keputusan yang telah dilakukan bagi menguji kesahihan } \\
\text { dan keboleh laksanaan prosedur tersebut (Evaluation). }\end{array}$ \\
\hline $\begin{array}{l}\text { Shaundra, Daily, Leonard, } \\
\text { Jörg, Babu, Gundersen, } \\
\text { Parmar (2015) }\end{array}$ & $\begin{array}{l}\text { The basic character of computational thin king is } \\
\text { abstraction and automation }\end{array}$ \\
\hline
\end{tabular}




\section{E. Kepentingan Guru Menggunakan Computer Thingking}

\begin{tabular}{|l|l|}
\hline Barr \& Stephenson (2011) & $\begin{array}{l}\text { Highlighted that a systematic change regarding CT } \\
\text { implementation in school couldnot be accomplished } \\
\text { without educational policies that include teacher } \\
\text { preparation to help educators understand and implement } \\
\text { CT in their teaching. Even though most of the } \\
\text { computational thinking initiatives we describe in this } \\
\text { chapter underline the necessity to train teachers in all } \\
\text { subject areas to embed CT, little has been done to } \\
\text { examine the instructional, curricular, and pedagogical } \\
\text { implications }\end{array}$ \\
\hline $\begin{array}{l}\text { Prieto-Rodriguez \& Berretta } \\
\text { (2014) }\end{array}$ & $\begin{array}{l}\text { Terdapat keperluan yang semakin meningkat untuk guru- } \\
\text { guru bersedia untuk mengintegrasikan CT ke dalam } \\
\text { mereka amalan kelas. }\end{array}$ \\
\hline
\end{tabular}

\section{Kriteria Literatur dan Kepustakaan}

Dalam menulis artikel, literatur dan kepustakaan bukanlah embel-embel atau penghias belaka. Bahkan itu juga menjadi pilar dalam sebuah artikel. Secara keseluruhan, batang tubuh artikel juga termaktub didalamnya literatur (Stinson, 1995). Sebagai komposisi artikel, maka ini juga memerlukan kecermatan dan keutuhan dalam proses penulisannya (Wekke, 2019a). kegiatan menelusuri literatur merupakan penelusuran (Wekke, 2019b) dan eksplorasi (Fulford, Lee, Lee, \& Kitson, 2004). Dengan demikian, perlu dicermati kriteria-kriteria dalam menggunakan literatur dan kepustakaan.

Untuk kemudahan menulis, menggunakan bantuan aplikasi berbasis teknologi informasi menjadi alat bantu untuk mewujudkan kecermatan menulis, namun sebagai alat tetap perlu pengecekan (Nur, Sabara, \& Wekke, 2018). Bagian penting yang perlu diperhatikan dalam setiap rujukan adalah kelengkapan informasi sebuah literatur. Termasuk dalam contoh pada halaman-halaman sebelumnya, ada literatur yang tidak mencantumkan tahun.

Selanjutnya adalah ketepatan informasi. Sebuah gaya penulisan, baik APA, atau MLA, atau gaya lainnya, memiliki cara tersendiri untuk setiap referensi. Ini dinyatakan sejak awal dalam panduan penulisan sebuah jurnal. Bisa jadi, jurnal tidak mengacu kepada gaya tertentu. Untuk itu, penulisan referensi sepenuhnya mengacu kepada pedoman yang disampaikan editor jurnal. Dalam menerapkan gaya penulisan referensi, ada pakem untuk setiap jenis, seperti buku, artikel jurnal, skripsi, dst. Penggunaan referensi yang akurat akan menjaga kohesi tulisan (Boyack, Small, \& Klavans, 2013).

Terdapat paling tidak lima gaya penulisan seperti yang disediakan Google Cendekia yaitu APA (American Phychological Association, 2010), Harvard Referencing Standards (Dwyer, 1995), Modern Language Association of America (Gibaldi, \& Achtert, 2003). Chicago Style (Turabian, 2013), dan Vancouver Style (Huth, 1981). Kelimanya secara otomatis sudah diformat oleh Google Scholar sehingga dapat digunakan langsung tanpa perlu menggunakan bantuan tambahan.

Berikutnya, sumber primer. Untuk memberikan argument diperlukan sumber utama dan bukan sumber kedua. Ketika menulis dengan sumber sekunder, kekhawatiran yang akan timbul adalah "apakah rujukan yang tertera itu sudah valid?". Sehingga untuk menjamin validitas informasi yang dirujuk perlu mengemukakan rujukan yang utama. Begitu pula dalam penulisan informasi, tidak lagi menggunakan gaya "si A dalam si B". ini berarti bahwa penulis tidak membaca rujukan yang ada tentang A secara langsung tetapi membacanya melalui tulisan si B. Penggunaan referensi memerlukan pengecekan ulang sehingga dalam 
penggunaan literatur merupakan kepustakaan yang sahih (Wekke, 2019c). aktivitas penelusuran literatur merupakan bagian yang sama pentingnya dengan pengumpulan data. Justru dengan adanya tahapan penelusuran literatur yang memadai, akan membantu dalam pengumpulan data sehingga sejak awal sudah menyatakan fokus research gap.

Terakhir, referensi yang dirujuk hendaknya mutakhir. Setiap bidang ilmu punya kesepakatan berbeda tentang ukuran mutakhir. Namun demikian, untuk ilmu sosial mungkin dapat dinyatakan dengan 10 tahun terakhir. Ini untuk menjadi penanda bahwa informasi yang disajikan dalam artikel merupakan maklumat yang terkini, bukan sesuatu yang basi apalagi sudah diluar percakapan saat ini. Jika terdapat beberapa referensi, maka direkomendasikan untuk memilih yang paling terbaru (Cals, \& Kotz, 2013). Dengan merujuk kepada referensi yang mutakhir, maka artikel tersebut akan senantiasa relevan. Keberadaan artikel yang tetap relevan dengan perkembangan terkini memungkinkan untuk dirujuk oleh ilmuwan maupun masyarakat awam.

Satu lagi, setiap kepustakaan yang dirujuk idealnya sudah tersedia dalam jaringan (online). Dengan menggunakan rujukan yang sudah daring, maka pembaca akan terbantu dalam merujuk kembali referensi jika memerlukan. Demikian pula, pembaca akan membantu penulis jikalau terjadi ketidakcermatan dalam proses penulisan. Sejak awal dengan menggunakan pangkalan data daring yang tepat akan membantu kecermatan dalam proses penulisan artikel (Buchanan, 2006). Dalam proses review, mitra bebestari akan mengecek kepustakaan. Jika itu tidak tersedia daring, maka akan menjadi kesukaran tersendiri bagi mitra bebestari dalam menelaah artikel yang ada. Saat menulis dengan menggunakan bantuan teknologi yang online, maka tantangan penulis adalah bagaimana alat bantu itu tidak mengacaukan proses menulis sehingga terjebak dalam kehinaan plagiat. Dengan menulis secara jujur tetap saja, merupakan sebuah aktivitas yang authentic (Putnam, 2001).

Akhirnya, untuk menulis sukses sebuah manuksrip artikel memerlukan kondisi yang kompleks. Kemampuan untuk menangani semua aspek itu menjadi bagian dalam proses persiapan untuk menerbitkan artikel (O'Connor, 2002). Menulis sama sekali tidak terkait dengan bakat ataupun keturunan. Menulis hany aterkait dengan keterampilan dan sematamata fokus (Debnath, Venkatesh, 2015). Dengan demikian, proses menulis tidak hanya terkait dengan literatur atau kepustakaan semata. Melainkan juga terkait dengan factor lain yang kompleks.

\section{Penutup}

Sumber-sumber informasi tidak pernah tunggal. Sehingga diperlukan kemampuan untuk menyintesis maklumat-maklumat yang tersedia. Dalam paparan artikel ini dikemukakan dua hal pertama yaitu langkah-langkah dalam proses sintesis artikel. Kedua, kriteria literatur dan penggunaanya dalam proses penulisan artikel. Kesemuanya saling terkait dan akan membantu penulis dalam menyelesaikan manuksrip yang sementara disiapkan.

\section{Daftar Pustaka}

American Psychological Association. (2010). Publication manual of the American psychological association Washington. DC: American Psychological Association.

Boyack, K. W., Small, H., \& Klavans, R. (2013). Improving the accuracy of co-citation clustering using full text. Journal of the American Society for Information Science and Technology, 64(9), 1759-1767.

Buchanan, R. A. (2006). Accuracy of cited references: The role of citation databases. College \& Research Libraries, 67(4), 292-303.

Cals, J. W., \& Kotz, D. (2013). Effective writing and publishing scientific papers, part VIII: references. Journal of clinical epidemiology, 66(11), 1198. 
Debnath, J., \& Venkatesh, M. D. (2015). Writing and publishing a scientific paper: facts, myths and realities. Medical journal, Armed Forces India, 71(2), 107.

Dwyer, M. (1995). A guide to the Harvard referencing system. British journal of Nursing, $4(10), 599-602$.

Fulford, T., Lee, D., Lee, D. J., \& Kitson, P. J. (2004). Literature, science and exploration in the Romantic era: Bodies of knowledge (Vol. 60). Cambridge University Press.

Gibaldi, J., \& Achtert, W. S. (2003). MLA handbook for writers of research papers. New York: Modern Language Association of America.

Huth, E. (1981). Style Matters: Manuscript requirements: the advance from Vancouver. $\mathrm{Br}$ Med J (Clin Res Ed), 282(6257), 55-56.

Nur, T., Sabara, H. Z., \& Wekke, I. S. (2018). Teknik Menulis Karya Ilmiah: Dengan 8 Senjata Aplikasi Pendukung Produktivitas Riset. Deepublish.

O'Connor, M. (2002). Writing successfully in science. Routledge.

Putnam, D. (2001). Authentic writing using online resources: Selling our words in the community. The English Journal, 90(5), 102-106.

Rahayu, T., \& Syafril, S. (2018). Cara Mensintesiskan Literature Review Dalam Penelitian. https://doi.org/10.31227/osf.io/4kqa2.

Stinson, S. W. (1995). Body of knowledge. Educational theory, 45(1), 43-54.

Turabian, K. L. (2013). A manual for writers of research papers, theses, and dissertations: Chicago style for students and researchers. University of Chicago Press.

Wekke, I. S. (2019a). Menulis Artikel Jurnal. https://doi.org/10.31227/osf.io/p4s3c.

Wekke, I. S. (2019b). Penelusuran Literatur Dalam Penulisan Artikel. https://doi.org/10.31227/osf.io/24ta6.

Wekke, I. S. (2019c). Validitas Referensi. https://doi.org/10.31227/osf.io/c4z5t.

\section{Biodata Penulis}

*Titik Rahayu, Mahasiswa Fakultas Pendidikan, Universiti Kebangsaan Malaysia.

*Syafrimen Syafril, dosen dengan jabatan fungsional Lektor Kepala UIN Raden Intan Lampung, Indonesia. Mendapat tugas tambahan sebagai Kepala Teknologi Informasi dan Pangkalan Data UIN Raden Intan 2015-2019.

*Ismail Suardi Wekke, dosen STAIN Sorong, Papua Barat, Indonesia. Adjunct Professor di Academy of Islamic Studies and Arabic Language (AISAL), College University of Yayasan Pahang, Malaysia. 